\title{
Construction and Implementation of Energy Control Center in Colleges and Universities
}

\author{
Liu Lin ${ }^{1, a}$, Yang Xiao ${ }^{2, a}$, Yang Shuo ${ }^{3, a}$, Hu Lushan ${ }^{4, b}$ \\ 1,2,3 Beijing Normal University,Beijing, 100875 \\ ${ }^{4}$ Beijing Xinxinghuaan Surveying and Mapping Co.,Ltd. , Beijing, 100081 \\ a hqzb@bnu.edu.cn, b bocsds@hotmail.com
}

\begin{abstract}
Keywords: Energy Control Center, energy saving reform.
Abstract. Based on the necessity and feasibility of implementation of Energy Control Center in colleges and universities, taking Beijing Normal University as an example, it introduces the design concept and technical architecture of the Energy Control Center, describes function modules, construction contents and social, economic and environmental benefits of the Energy Management System in this paper. Adopting automation, information technology and centralized management model, the Energy Control Center carries on refined energy saving reform according to the actual situation of campus buildings, which has made great efforts to enhance the level of energy management and remote monitoring, producing guiding significance to the construction of resource-efficient campuses at home.
\end{abstract}

\section{Introduction}

At the beginning of the 21 st century, the schooling philosophy of green university emerges in domestic and international colleges and universities. In April, 2007, Global Sustainable Development Campus Network was founded; low-carbon and sustainable development of buildings and operation of college campus, which owns high energy consumption and great potentials in energy saving, became focus of attention. In 2009, the demonstration construction of Chinese campus energy saving supervision system became a significant turning point of green campus construction. From virtuality to reality and from reality to extension in depth, it started the green development of college campuses in China.

So far, there are more than 3000 colleges and universities in China with a large amount of campus buildings. Their energy demand grows rigidly, and the proportion of energy consumption on campus in total social energy consumption increases gradually; the reality draws extensive attention of the society. Colleges and universities are a major force for leading social development; college teachers and students are leaders and practitioners of social civilized conducts. Construction of conservation-oriented campus is an important part of conservation-minded society construction, need of college self-development and social responsibility is undertaken by colleges and universities.

Construction of Energy Control Center in Beijing Normal University (hereinafter referred as BNU)is the first step for building a conservation-oriented campus and a significant measure for guaranteeing realization of the anticipated goal of conservation-oriented campus construction. It could both enhance the scientific awareness of teachers and students on campus energy consumption, and do scientific analysis to energy facilities, energy rules and energy saving amount, as well as work out workable energy saving quantitative indicators with specific management measures. Construction of conservation-oriented campus in BNU focuses on three aspects of management energy conservation, concept energy conservation and technology energy conservation, in order to try to lower down school running cost and improve energy efficiency. It creates conditions for improving long-term benign rapid development of the University, and sets an example for and leads the conservation-oriented campus and conservation-minded society construction. 


\section{Design concept}

The Energy Control Center is an important component of the conservation-oriented campus. It should take energy saving construction as the core of energy control in design and integrate functions of data collection, program design, energy saving analysis, management $\&$ monitoring and balancing prediction with comprehensive and step-down philosophy to produce energy control integration.

Conservation-oriented campus construction can be traced back to 1985 in BNU. In 2008, new investigation and statistics was made to equipment of water supply, power supply, heat supply and central air-conditioning on campus, and more accurate energy consumption data was obtained. In 2013, the Energy Control Center completed the 1st phase construction of energy saving reform to initially build up 1st class monitoring network, and the campus layout of water and electricity meters metering in each building. In the coming days, it will further advance follow-up construction of heat-supply network, steam network, lighting system and metering in each room \& each device terminal to complete an energy control system of various energy networks covering all buildings and major energy consumption facilities on campus, provide a digital energy management platform, and lay a solid foundation for building green campus.

The Energy Control Center of BNU plans to complete the 2nd phase construction of energy saving reform, realize on-line monitoring to heating energy of each building and supply heat in different periods and different districts. It can do remote on-off control, real-time monitoring and maintaining to campus street lights and landscape lighting systems according to light intensity. Based on management requirements, it could do remote on-off control, real-time monitoring, measurement \& assessment and charge management. In supply of water and power, it realizes metering in each room to lay a foundation for public power indexation. It also makes remote calculation to single air-conditioning in teaching and office areas, to carry on indexation power consumption and improve energy efficiency.

\section{Technical architecture}

The Energy Control Center of BNU is mainly used for energy consumption calculation, data analysis, data statistics, energy saving analysis and energy saving indicator management of buildings and facilities on campus. The Campus Building Energy Control System comprises of metering tools, data collection \& transformation devices ("gateway equipment" in this Guideline), data transmission network, data transfer station, data server and management software. The system should take use of BS software architecture based on internet technology. It also should be equipped with functions of energy consumption data real-time collection \& communication, remote transmission, automatic sorting \& statistics, data analysis, index comparison, graph display, report management, data storage and upload to meet the contents and requirements of energy management on campus.

\section{Network structure}

Network structure of the Energy Control System of BNU is as Fig.1 .

\section{Energy management}

BNU set up a leading group for energy conservation, to carry on a collection of energy saving reform measures as it pays high attention to energy management. In 2008, the University made full investigation and analysis to all energy consumption departments, more than 260 buildings (almost 750,000 square meters) and water supply, power supply, heat supply and air-conditioning facilities, and obtained firsthand scientific and reliable energy consumption data. In 2009 and 2012, the University carried out two energy audits which is a basis for the university to advance water saving campus construction. Through the energy audits, it could analyze and learn the energy management level and energy consumption status more accurately. It can also troubleshoot, understand the weak link, look for energy saving direction and develop energy saving potentials to realize informationization and scientification of energy management; and promote improvement of Energy Control Center's supervision and assessment. 


\section{Energy security}

Physical isolation

In design, the physical isolation system of the program comprises of two aspects as follows:

(1) DiskControl: to control hard disk on-off. It could power off the hard disk, which is irreversible unless the computer is restarted. Otherwise, the powered-off hard disk can't work with any measure.

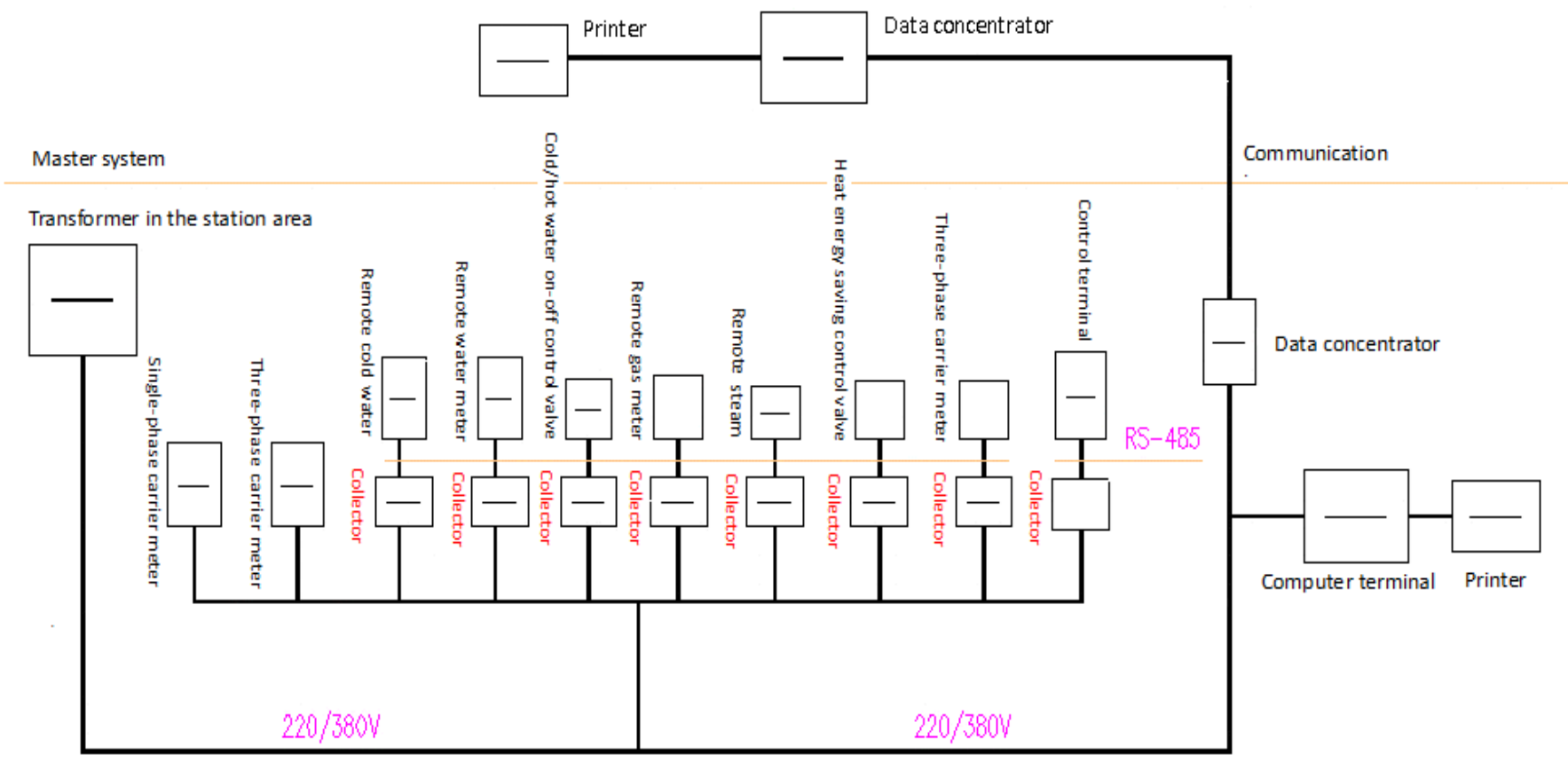

Fig.1 Network structure of the Energy Control System

DataEncrypt: to realize network isolation. Encrypt data is transmitted in intranet and internet with different encryption algorithm to form two sets of virtual networks. On the other hand, encrypt the stored data on intranet and internet hard disks to guarantee data absolute security.

Its technical features consists of (1) multi-networks absolute isolation (2) data encryption (3) safe data exchange (4) log management

\section{Integrated wiring}

The Energy Control System of BNU mainly takes use of star topology integrated wiring way with standard, usable, economic, expandable and flexible principles to wiring separately in each sub-system and make each sub-system to be an independent cell block. Therefore, change of any sub-system will never influence other subsystems. Horizontal wiring which destroys building decoration and appearance is not necessary for new integration need other than set time.

\section{Border defense}

For border security defense, the border defense solution of this program consists of security gateway, intrusion prevention system and security management platform. The security gateway SecPath firewall integrates packet filter and state inspection technologies in 2-4 layers and cooperates with SecPath IPS intrusion prevention system in 4-7 layers to produce comprehensive security defense in 2-7 layers. It can effectively protect the system from attack of illegal access, DDoS, virus, worm and page tampering and conduct unified security management to security gateway, intrusion prevention system and facilities from different suppliers through security management platform.

In order to carry out security service work, the program will focus on following contents for integrating the reality of the Energy Control Center of BNU:

1) Pay high attention to information security management and strengthen the leadership. 
2) Establish and improve security service rules and regulations and intensify advertising and training.

3) Follow security service management system and rules strictly.

4) Develop security service work inspection carefully and make sure the implementation of all measures.

5) Make clear security service management responsibility and treat disciplines seriously.

\section{Equipment selection}

Equipment selection means to investigate, analyze and compare different equipment to determine an optimum proposal according to principles of advanced technology, reasonable price and application, and requirements of feasibility, maintainability and operability.

1.The metering equipment should meet requirements of accuracy, energy conservation, reliability, manageability and security.

2.The network system equipment should follow requirements of expansibility, standard and openness.

Table 4-1 Purchase Order of Major -Equipment for the $2^{\text {nd }}$ Phase of Energy Saving Reform Project

\begin{tabular}{|c|c|c|c|c|c|}
\hline Project & No. & Name & Model & Unit & Quantity \\
\hline \multirow{6}{*}{$\begin{array}{l}\text { Energy monitoring and } \\
\text { control of heat supply } \\
\text { system }\end{array}$} & 1 & Electrically operated valve & & Set & 81 \\
\hline & 2 & Heat meter & & Set & 81 \\
\hline & 3 & Butterfly valve & & Set & 162 \\
\hline & 4 & Pressure gage & & Set & 162 \\
\hline & 5 & Power line carrier collector & & Set & 81 \\
\hline & 6 & Power line carrier controller & & Set & 81 \\
\hline \multirow{5}{*}{$\begin{array}{l}\text { Power and water supply } \\
\text { metering in each room }\end{array}$} & 1 & Carrier network optimizer & & Set & 48 \\
\hline & 2 & $\begin{array}{l}\text { Triphase carrier ammeter (with } \\
\text { instrument transformer ) }\end{array}$ & & Set & 120 \\
\hline & 3 & Data acquisition unit & & Set & 304 \\
\hline & 4 & Remote single phase ammeter & & Set & 5200 \\
\hline & 5 & Remote water meter & & Set & 184 \\
\hline \multirow{3}{*}{$\begin{array}{l}\text { Network integration and } \\
\text { software upgrading }\end{array}$} & 1 & System software & & Set & 1 \\
\hline & 2 & Database software & & Set & 1 \\
\hline & 3 & Other software & & Set & 1 \\
\hline
\end{tabular}

\section{Functional module}

Since starting of Energy Control Center energy conservation program in 2008, BNU owns three independent systems with different functions:

\section{Remote monitoring system of heating boiler house:}

1. Online monitoring of water, power \& gas consumption instead of manual meter-reading;

2. Accurate and timely adjustment of main water mixing valve instead of manual operation;

3. Newly-added warning function to monitor unusual conditions in real time instead of manual analysis and judgment.

\section{Prepayment management system of students' dormitory}

1. Power supply of students' dormitory is with one meter in each room, quota supply and charging for that over quota.

2. It can recognize high power electrical appliances out of lines used in dormitory.

3. Online monitoring to power consumption of dormitory. 


\section{1st phase of energy saving reform on campus}

In 2013, the University Energy Control Center completed the 1st phase construction of energy saving reform to realize energy consumption data calculation and control in each building. It measures total dynamic electricity consumption, total lighting electricity consumption, total water consumption and total heat consumption of all buildings on campus (excluding family area) and conduct remote real-time monitoring.

\section{Achievement benefits}

\section{Social benefits}

Education is a measure of social structure and social order reproduction, the basic function of which is to "socialize" the young generation. As a normal university, most graduates of BNU will work on education in various education authorities and colleges and secondary schools. College life is an important stage of young people maturing. Teachers and students must benefit from some saving education on reasonable consumption concept development in college days which have impact on students for a whole life. As graduates go out of campus, the good consumption concept and saving awareness will be extended to the society and advantage of education in resource conservation will emerge. Moreover, it indicates the school motto of BNU "Learn to be an excellent teacher; act as an examplary person" and creates a saving education environment conforming to demands of the time. Hence, the energy saving reform construction of the Energy Control Center on campus has significant social benefits.

\section{Economic benefits}

Although the energy control system can't produce economic benefits directly, realization of precision management through transformation of energy consumption fine measurement system and digital network transmission system will drive energy consumption departments on campus to select energy-efficient facilities, take use of energy saving and water saving measures, intensify resource utilization management and improve service efficiency voluntarily to achieve the saving goal.

According to the statistics, by end of 2012, water, power and gas consumption of BNU are $1147100 \mathrm{~m}^{3}, 46270260 \mathrm{kwh}$ and $13662365 \mathrm{Nm}^{3}$ respectively. Based on figures, water, power and gas consumption per capita of BNU are $3.7 \mathrm{~m}^{3}$ /person $\cdot$ month, $148 \mathrm{kwh} /$ person $\cdot$ month and $44 \mathrm{~m}^{3}$ /person • month respectively.

In accordance with the general planning of conservation-oriented campus construction of BNU, water, power and gas consumption per capita of BNU shall be $3.2 \mathrm{~m}^{3} /$ person $\cdot$ month, $110 \mathrm{kwh} /$ person - month and $30 \mathrm{~m}^{3} /$ person $\bullet$ month respectively in 2015 .

From the above, please see the below table for energy conservation of the program after project construction:

Table 5-1 Energy Conservation Comparison Table

\begin{tabular}{|c|c|c|c|c|}
\hline Energy type & Unit & $\begin{array}{c}\text { Energy } \\
\text { consumption in } \\
\mathbf{2 0 1 2}\end{array}$ & $\begin{array}{c}\text { Target energy } \\
\text { consumption in 2015 }\end{array}$ & $\begin{array}{c}\text { Saving quantity } \\
\text { per capita }\end{array}$ \\
\hline Water & $\mathrm{m}^{3}$ /person·month & 3.7 & 3.2 & 0.5 \\
\hline Power & $\mathrm{kwh} /$ person·month & 148 & 110 & 38 \\
\hline Natural gas & $\mathrm{m}^{3}$ /person·month & 44 & 30 & 14 \\
\hline
\end{tabular}

In the operation stage, the expected operating cost mainly includes management cost $(3 * 0.8 * 12=\mathrm{RMB} 288,000)$, maintenance cost $(873 * 0.05=\mathrm{RMB} 437,000)$ and labor cost $(5 * 0.5 * 12=\mathrm{RMB} 300,000)$ with total expected operating cost of RMB865,000/year. According to 
energy conservation level, the expected energy conservation cost of the program is RMB6,010,000/year or so. Therefore, the economic benefit produced by the program is obvious.

\section{Environmental benefits}

The Energy Control Center construction in BNU promotes utilization of various energy-saving measures and reduces pollution from building energy consumption. Renewable energy sources are used to make campus energy consumption greener and cleaner. Through a collection of technical measures for energy saving buildings, emissions of $\mathrm{CO}_{2}, \mathrm{SO}_{2}, \mathrm{CO}, \mathrm{NO}_{\mathrm{x}}, \mathrm{HC}$ and smoke dust are reduced significantly, which contributes to air pollution prevention of Beijing. It also takes use of reclaimed water reuse and water saving measures on campus driving the quality of water environment on campus to meet water quality standard and taking full use of reclaimed water to make water resource conservation come true.

In conservation-oriented campus construction, it will lower down 7693 tons of standard coal consumption each year in the comparable base of 2013 with measures of reducing resource consumption and improvement of use efficiency. It will lower down 11.4 tons of standard coal consumption each year with demonstrative utilization of renewable energy resources. It equals to emission reduction of 21337 tons of $\mathrm{CO}_{2}, 642$ tons of $\mathrm{SO}_{2}$ and 321 tons of $\mathrm{NO}_{\mathrm{x}}$. In a word, conservation-oriented campus building energy saving reform construction has great environmental benefits.

\section{Conclusions}

As a state university, the normal operation of BNU needs a large amount of energy consumption and produces many kinds of secondary energy. Plenty of energy saving works shall be done to save energy, protect environment, reduce school running cost and improve the teaching, learning and living conditions of students and teachers. The Energy Control Center initially achieves the transition from extensive energy management to refined, informationized and remote control management, winning great social, economic and environmental benefits.

The Energy Control Center is an important platform for energy management and energy saving construction on campus. To promote development of energy saving reform program of the Energy Control Center and to further drive the following construction of heat network, steam network, campus lighting and metering in each room and on each device terminal is the only way for conservation-oriented campus construction of BNU. It will have a profound impact on energy management level improvement of domestic colleges and universities and even the whole society.

\section{Acknowledgements}

Supported by the Fundamental Research Funds for the Central Universities.

\section{References}

[1]. Gerhard Hausladen. Michael de Saldanha. Petra Liedl. Christina Sager. Climate Design-Solutions for Buildings that Can Do More with Less Technology. Birkhauser Publishers for Architecture.2004

[2]. Will Toor. Transportion \& Sustainable Campus Communities. Island Press. 2004

[3]. Brian Edwards. Green Architecture. WILEY-ACADEMY. 2001

[4] Ministry of Housing and Urban-Rural Development of PRC, Ministry of Education, Building Technology Guideline for Campus Building Energy Saving Monitoring System in Colleges and Universities (Building Technology Press No. 163[2009])

[5] Zhang Tong, Green Northern Europe, Southeast University Press, 2008 
[6] Li Haiying et al., Ecological Building Energy Conservation Technology and Case Analysis [M], Beijing: China Electric Power Press, 2007 